\title{
Spatial associations between seabirds and prey: effects of large-scale prey abundance on small- scale seabird distribution
}

\author{
Lucy S. Vlietstra* \\ Department of Ecology and Evolutionary Biology, University of California, Irvine, California 92697, USA \\ Present address: Section of Marine Science, Department of Science, 27 Mohegan Dr., US Coast Guard Academy, \\ New London, Connecticut 06320, USA
}

\begin{abstract}
The purpose of this study was to examine whether variation in the extent to which marine birds track prey over small spatial scales can be attributed, in part, to fluctuations in regional prey abundance. The distributions of 4 marine bird species were compared to the distribution of acoustically determined prey biomass on days with contrasting prey abundances measured over a 10 $\times 20 \mathrm{~km}$ (regional) spatial scale. Spatial associations were measured at smaller (local) spatial scales, ranging from 0.2 to $7.6 \mathrm{~km}$. Spatial concordance (i.e. overlap) between the distribution of acoustic biomass and the rhinoceros auklet Cerorhinca monocerata and between acoustic biomass and the Pacific loon Gavia pacifica at the smallest spatial scale $(0.2 \mathrm{~km})$ was greater on days when regional prey abundance was relatively low than on days when regional prey abundance was relatively high. This pattern was not evident in Brandt's cormorant Phalacrocorax penicillatus or the common murre Uria aalge. The densities of all 4 marine bird species examined were, however, only significantly correlated with densities of acoustic biomass on days when regional prey abundance was relatively low. I propose that short-term fluctuations in regional prey abundance account for some of the widespread variation previously observed in the strength of spatial associations between marine birds and their prey.
\end{abstract}

KEY WORDS: Predator-prey interactions - Spatial relationships $\cdot$ Numerical concordance $\cdot$ Hydroacoustic surveys $\cdot$ Marine bird distribution $\cdot$ Foraging behavior

\section{INTRODUCTION}

For trophic interactions to occur, predators must be spatially concordant with their prey; therefore, one expects the distribution of predators while foraging to reflect the distribution of their prey, if not directly, then at least over small spatial scales (MacArthur \& Pianka 1966, Fretwell 1972, Fagen 1987). Marine birds, however, appear to show little concordance with their prey over small $(<10 \mathrm{~km})$ spatial scales (Woodby 1984, Obst 1985, Safina \& Burger 1985, Heinemann et al. 1989, Hunt et al. 1992, Logerwell \& Hargreaves 1996, Fauchald et al. 2000, Skov et al. 2000). When concordance does occur, it often seems temporally intermittent. For example, densities of the common murre Uria aalge at sea off the coast of Newfoundland were found by Schneider \& Piatt (1986) to be correlated with densities of capelin Mallotus villosus at small spatial scales (2 to $6 \mathrm{~km}$ ) only on certain sampling days. Densities of common murres and the thick-billed murre Uria lomvia in the North Sea were found by Wright \& Begg (1997) to be correlated with sandeel Ammodytes marinus densities during the breeding season, but not during other times of year. Apparently, the ability (or need) of marine birds to track prey over small spatial scales varies over time according to internal or environmental factors.

One factor that may influence the strength of smallscale correlations between marine bird and prey densities is prey availability over larger spatial scales. The 
amount of prey available to a predator is known to directly affect one's foraging success, and predators adjust their foraging behavior according to energy intake (Schoener 1971, Lima 1983, Stephens \& Krebs 1987). These adjustments may lead to a nonlinear relationship between the strength of predator-prey associations and regional prey abundance. For example, when prey is superabundant, marine birds may encounter prey so frequently that tracking prey is energetically inefficient. Instead, birds might function as sit-and-wait predators or they may feed on nearby prey instead of traveling to sites with maximum prey abundance (Huey \& Pianka 1981, Pianka 1986). The result would be little coherence between predator and prey densities. As regional prey abundance declines to intermediate levels, patch depletion by neighboring conspecifics may reduce a predator's rate of food intake, causing predators to distribute themselves according to the Ideal Free Distribution (IFD), a pattern in which predator densities are distributed in direct proportion to prey densities (Fretwell \& Lucas 1970). As regional prey abundance continues to decline, constraints should begin to limit a predator's ability to track prey. For instance, competitors may exclude others from certain patches, or predators may lack information on prey distribution that is needed to design effective foraging strategies. Either of these effects would lead to a spatial mismatch between predator and prey densities (Messier et al. 1990, Gray \& Kennedy 1994, Spencer et al. 1996). If poor foraging conditions persist, predators should leave the region in search of more abundant food supplies.

The purpose of this study was to test the hypothesis that variation in the degree to which marine bird densities reflect prey densities over small spatial scales can be attributed to fluctuations in prey abundance over larger spatial scales. To test this hypothesis, I compared the frequency of small-scale spatial overlap (i.e. 'spatial concordance') between 4 marine bird species, including Brandt's cormorant Phalacrocorax penicillatus, the common murre Uria aalge, the Pacific loon Gavia pacifica, and the rhinoceros auklet Cerorhinca monocerata, and acoustically determined prey biomass (hereafter, 'acoustic biomass') on days with contrasting regional prey abundance. I also compared the strength of spatial correlation between densities of marine birds and acoustic biomass ('numerical concordance') on days with contrasting regional prey abundance. Hereafter, 'local' refers to spatial scales ranging from 0.2 to $7.6 \mathrm{~km}$, and 'regional' refers to the spatial scale of the study site, $10 \times 20 \mathrm{~km}$. This study addresses processes that affect seabird distribution over fine spatial scales, such as foraging in individual prey patches, rather than processes affecting seabird distribution over larger spatial scales (Hunt \& Schneider 1987).

\section{MATERIALS AND METHODS}

Sampling was conducted in Monterey Bay, California $\left(36^{\circ} 45^{\prime} \mathrm{N}, 121^{\circ} 40^{\prime} \mathrm{W}\right)$, from 28 January to 20 March 1998, 11 February to 17 March 1999, and 24 November 1999 to 21 March 2000. Monterey Bay is one of the most productive coastal regions in North America, a distinction owed to the seasonal (March to September) upwelling of nutrient-rich water from Monterey Canyon (Garrison 1979, Breaker \& Broenkow 1994, Kudela \& Dugdale 1996, J. F. Pennington \& F. P. Chavez unpubl.). Apart from the canyon, Monterey Bay is largely neritic, with depths generally not exceeding $100 \mathrm{~m}$ (Fig. 1). The
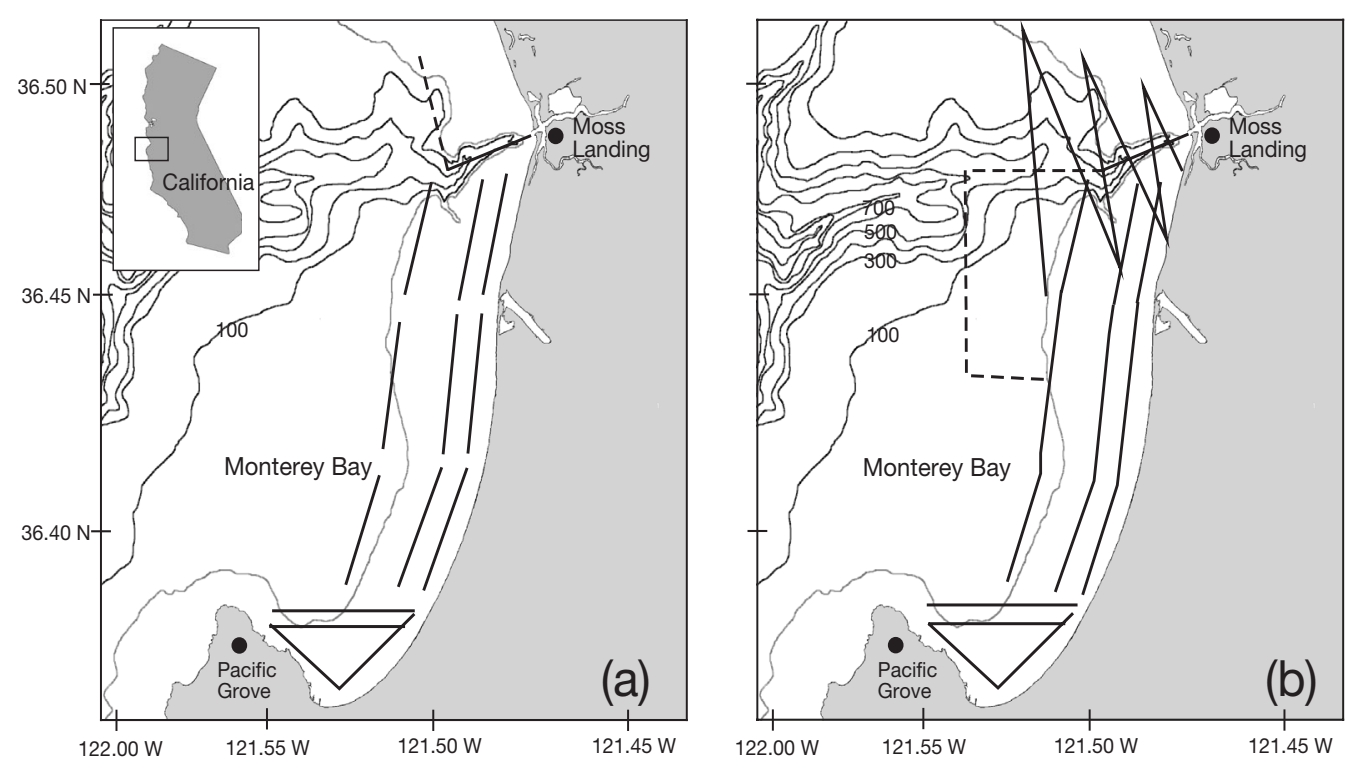

Fig. 1. Monterey Bay, showing transect locations in (a) January to March 1998 and February to March 1999, and (b) November 1999 to January 2000. Solid lines are transects on which repeated hydroacoustic surveys and marine bird observations were conducted. Dashed lines represent transects sampled opportunistically. Grey line nearest the coastline in each panel is the $50 \mathrm{~m}$ bathymetric contours 
central and southern portions of the bay, where nearly all of the sampling took place, contain canyon, sandy bottom, shale bed, and kelp forest habitats.

Brandt's cormorants, common murres, Pacific loons, and rhinoceros auklets are the 4 most abundant marine bird species in nearshore $(<3 \mathrm{~km})$ Monterey Bay during winter (Mason 1997, this study). During this time, Brandt's cormorants and common murres primarily consume midwater schooling fish, including the northern anchovy Engraulis mordax and market squid Loligo opalescens, as well as some juvenile rockfish Sebastes spp. and herring Clupea pallasii (Morejohn et al. 1978, Ainley et al. 1981, Croll 1989, Ainley et al. 1996). Common murres may also take some euphausiids, but murres in Monterey Bay are reported to feed less heavily upon euphausiids than do murres elsewhere (Croll 1989, H. Nevins unpubl. data). Both cormorants and murres typically capture prey at depths up to 70 to $100 \mathrm{~m}$; however, both are known to reach depths exceeding 100 m (Clay 1911, Piatt \& Nettleship 1985, Ainley 1990, Ainley et al. 2002 and references therein).

During winter, Pacific loons and rhinoceros auklets in Monterey Bay take primarily northern anchovies and market squid (Baltz \& Morejohn 1977, Morejohn et al. 1978). Unlike rhinoceros auklets elsewhere in the North Pacific (Ainley \& Sanger 1979), auklets off the coast of California appear to maintain primarily piscivorous diets (Gaston \& Dechesne 1996 and references therein). Rhinoceros auklets typically dive to depths within $30 \mathrm{~m}$ of the surface (Burger et al. 1993) but are known to reach depths up to $60 \mathrm{~m}$ (Burger et al. 1993, Kuroki et al. 2003). Depths at which Pacific loons capture prey are unknown, but they are likely comparable to those of common loons Gavia immer, which dive to approximately $60 \mathrm{~m}$ (Roberts 1932).

Potential prey availability. Prey availability to marine birds was estimated with hydroacoustic surveys of the abundance and distribution of acoustic biomass along 25 fixed transects in nearshore Monterey Bay (Fig. 1). Other studies that have coupled hydroacoustic surveys with net sampling have shown that acoustic biomass can be a reliable estimator of fish biomass if appropriate parameters are applied during data processing (Watkins \& Brierley 1996, Horne \& Clay 1998). It was not feasible to determine the composition of acoustic biomass with net sampling because fish avoid nets, especially during the day, and the cost of employing appropriate vessels for fish sampling was prohibitive; therefore, descriptions of the local fish community, published target strengths of local and similar species, and information on local bird diets during winter were used to select a sound threshold, $-60 \mathrm{~dB}$ (decibels), below which acoustic data were removed from the analysis (Morejohn et al. 1978, Caillet et al. 1979, Ainley et al. 1981, 1996, Croll 1989,
H. Nevins unpubl. data). As most euphausiids have low target strengths (TS $<-70 \mathrm{~dB}_{\text {animal }}{ }^{-1}$ at $120 \mathrm{kHz}$ frequency) relative to fish and squid (TS $>-55 \mathrm{~dB}$ ani$\mathrm{mal}^{-1}$ ), removing backscatter below $-60 \mathrm{~dB}$ should have excluded most plankton, leaving acoustic biomass pertaining to fish with swim bladders, squid, or dense patches of large zooplankton (Pieper 1978, Vaughan \& Recksiek 1979, Barange et al. 1996, Misund \& Beltestad 1996, Brierley et al. 1998, Gutiérrez \& MacLennan 1998, McGehee et al. 1998, Kawabata 1999, Coyle \& Pinchuk 2002).

Hydroacoustic surveys encompassed a region of approximately $10 \times 20 \mathrm{~km}$ in the south central portion of nearshore Monterey Bay. This scale hereafter represents the regional spatial scale at which the study was conducted. Transects within this region ranged in length from 2.5 to $13.0 \mathrm{~km}$. Most transects were located within $3.2 \mathrm{~km}$ of shore at depths ranging from 20 to $80 \mathrm{~m}$. The exceptions were 7 transects sampled during 2000, which were located over Monterey Canyon at depths that sometimes exceeded $1000 \mathrm{~m}$, and other transects sampled opportunistically as time and weather permitted (Fig. 1b). All sampling, except that conducted opportunistically, was partially stratified over time of day and season; that is, routine surveys started and ended at Moss Landing, California, but the direction in which transects were traveled was randomized. This schedule resulted in a given transect being sampled at various times of day throughout the study period. Surveys were conducted approximately twice every $2 \mathrm{wk}$, weather permitting, and were completed within $1 \mathrm{~d}$, typically within 5 to $7 \mathrm{~h}$. Sampling was terminated if wind speed exceeded $7.7 \mathrm{~m} \mathrm{~s}^{-1}$ (15 knots).

Surveys were conducted aboard the 35' RV 'Ed Ricketts'. The hydroacoustic system consisted of a $6^{\circ}$ singlebeam, BioSonics DT4000 digital echosounder, with a $120 \mathrm{kHz}$ transducer mounted on a hydrodynamic fin. The fin was towed behind the boat at 9 to $11 \mathrm{~km} \mathrm{~h}^{-1}$ (5 to 6 knots). A digital echogram of acoustic biomass in the water column to a depth of $100 \mathrm{~m}$ was obtained for each transect. To avoid surface interference, acoustic biomass in the top $4 \mathrm{~m}$ of the water column was not measured. Echograms were tagged with a continuous record of time and location (latitude-longitude).

Hydroacoustic data were processed with Visual Analyzer 4.0.2 software (BioSonics 2000). During processing, echograms were divided into $0.2 \mathrm{~km}$ vertical reports and $0.001 \mathrm{~km}$ horizontal strata. As decibels are measured on an exponential scale, backscatter was converted from decibels to a linear scale for statistical analysis. Linear values were converted back to decibels for graphic presentation.

Marine birds. Marine bird observations were made concurrently with hydroacoustic surveys. While the 
boat was underway, an observer positioned on the flying bridge ( $2.3 \mathrm{~m}$ above sea level) counted all birds that occurred within $300 \mathrm{~m}$ of both sides of the boat. As the echosounder measured acoustic biomass directly below the boat, some birds included in the survey may not have been associated with biomass detected by the echosounder. For each marine bird sighting, the species and behavior (flying, resting, feeding, preening, other) of each bird was recorded directly into a laptop computer that tagged each sighting with time of day and location (latitude-longitude). As I was only interested in birds that had been foraging recently, flying birds were excluded from the analysis. The abundance of each species was summed over $0.2 \mathrm{~km}$ intervals for comparison with acoustic biomass.

Data analysis. Prey availability to marine birds was evaluated with respect to the amount of acoustic biomass integrated to the maximum typical diving depth reported for each species (see 'Materials and methods', Table 1). The magnitude of short-term fluctuations in prey availability to marine birds was measured by calculating the percentage difference in the acoustic biomass density between consecutive sampling days. As sampling was conducted approximately once a week (mean $\pm \mathrm{SE}$; $6.5 \pm 1.0 \mathrm{~d}$ ), short-term fluctuations typically refer to minimum weekly fluctuations in regional prey abundance.

Spatial and numerical concordance between marine birds and acoustic biomass was first evaluated with respect to data collected on all survey days combined. Survey days were then separated into 2 categories according to the median acoustic biomass density $\left(\mathrm{dB} \mathrm{km}^{-1}\right)$ measured throughout the study period (Table 1). Days with regional prey abundance below the median were considered days on which regional prey abundance was relatively low, and days with regional prey abundance above the median were considered days on which regional prey abundance was relatively high. In the third analysis, days were further separated into categories of very low, low, high, and very high regional prey abundance according to the median density of acoustic biomass measured on days with low and high regional prey abundance (Table 1). I emphasize that these categories are intended to reflect relative, not absolute, levels of regional prey abundance at the study site.

The relationship between regional prey abundance and overall marine bird abundance at the study site was evaluated with a Student's $t$-test, which compared the mean density of each bird species present on days with low and high regional prey abundance. Univariate analysis of variance (ANOVA) was used to compare the mean density of each marine bird species with acoustic biomass density among days with very low, low, high, and very high regional prey abundance.

Autocorrelation: Before evaluating spatial and numerical concordance between marine birds and acoustic biomass, I examined the distribution of acoustic biomass and, separately, the distribution of marine birds for spatial autocorrelation. Autocorrelation is a measure of the degree to which a variable is correlated with values of that same variable (i.e. itself) in adjacent or nearby measurement intervals. Autocorrelation can present problems in correlation analyses by causing artificial confidence intervals around correlation coefficients, inflating the likelihood of either Type I or Type II errors, depending upon the spatial structure of both variables (Legendre 1993, Legendre et al. 2002, Diniz-Filho et al. 2003). Autocorrelation was measured by calculating Moran's I statistics for each variable at the same spatial scales used to evaluate numerical concordance (see below). The

Table 1. Density of acoustic biomass and marine birds ( $\mathrm{n}=33$ surveys) in nearshore Monterey Bay during the winters of 1998 to 2000

\begin{tabular}{|c|c|c|c|c|c|c|c|}
\hline \multirow[b]{2}{*}{ Species } & \multirow[b]{2}{*}{$\begin{array}{l}\text { Depth }^{\mathrm{a}} \\
\quad(\mathrm{m})\end{array}$} & \multirow[b]{2}{*}{$\begin{array}{l}\text { Mean (SE) \% } \\
\text { difference be- } \\
\text { tween conse- } \\
\text { cutive surveys }\end{array}$} & \multicolumn{4}{|c|}{ Acoustic biomass density $\left(\mathrm{dB} \mathrm{km}^{-1} \mathrm{~d}^{-1}\right)$} & \multirow[b]{2}{*}{$\begin{array}{l}\text { Mean density (SE) } \\
\text { of marine birds } \\
\text { (no. } \mathrm{km}^{-1} \mathrm{~d}^{-1} ; \\
\text { all sampling } \\
\text { days) }\end{array}$} \\
\hline & & & $\begin{array}{l}\text { Median } \\
\text { (all } \\
\text { sampling } \\
\text { days) }\end{array}$ & $\begin{array}{c}\text { Range } \\
\text { (all } \\
\text { sampling } \\
\text { days) }\end{array}$ & $\begin{array}{l}\text { Median } \\
\text { (days with } \\
\text { low prey } \\
\text { abundance) }\end{array}$ & $\begin{array}{l}\text { Median } \\
\text { (days with } \\
\text { high prey } \\
\text { abundance) }\end{array}$ & \\
\hline Rhinoceros auklet & 30 & $1483(701)$ & -47.9 & -66.0 to -28.3 & -54.8 & -37.9 & $5.0(1.6)$ \\
\hline Pacific loon & 60 & $1110(428)$ & -38.7 & -58.1 to -24.6 & -44.6 & -32.2 & $3.7(1.0)$ \\
\hline Common murre & 100 & $1478(521)$ & -37.1 & -58.1 to -22.2 & -37.1 & -29.9 & $2.9(0.8)$ \\
\hline Brandt's cormorant & 100 & $1478(521)$ & -37.1 & -58.1 to -22.2 & -37.1 & -29.9 & $2.3(0.5)$ \\
\hline
\end{tabular}


statistical significance of each Moran's I statistic was tested with Monte Carlo simulations. Marine birds and acoustic biomass were considered autocorrelated if the Moran's I for the observed distribution was greater than (positive autocorrelation) or less than (negative autocorrelation) those for random distributions in over $95 \%$ of 99 randomized trials.

When a variable was autocorrelated, marine birds were regressed against acoustic biomass, and the residuals were tested for autocorrelation. This method allowed for the spatial structure of the dataset to be evaluated after accounting for possible correlative relationships between the 2 variables (Diniz-Filho et al. 2003). If the residuals were not autocorrelated, then the likelihood of Type I or Type II errors for that comparison was equal to cases in which autocorrelation did not occur. If the residuals were autocorrelated, then the significance of the original correlation could not be properly interpreted due to potential biases introduced by spatial structure in the autocorrelated variable (Diniz-Filho et al. 2003), and these comparisons were omitted from the analysis.

Spatial concordance: In the absence of autocorrelation among the residuals at the $0.2 \mathrm{~km}$ spatial scale, spatial concordance between marine birds and acoustic biomass was measured by determining the proportion of $0.2 \mathrm{~km}$ measurement intervals that contained birds that also contained acoustic biomass. At larger spatial scales ( $\geq 0.8 \mathrm{~km})$, nearly all measurement intervals contained at least some acoustic biomass, causing the proportion of intervals containing both birds and acoustic biomass to approximate to 1.0 in nearly every comparison. Analyses of spatial concordance were, therefore, limited to the smallest $(0.2 \mathrm{~km})$ spatial scale.

Spatial concordance was evaluated for data collected on days with relatively low regional prey abundance and, separately, on days with high regional prey abundance. Only measurement intervals containing values of acoustic biomass that occurred on days in both categories were used. This range included all measurement intervals from days with low regional prey abundance and 98.9 to $99.8 \%$ of intervals (depending on depth) on days with high regional prey abundance.

To determine whether marine birds co-occurred with acoustic biomass more often than expected by chance, the proportion of intervals that contained acoustic biomass was compared to the proportion of intervals that contained birds that also contained acoustic biomass, i.e.

$$
\frac{R_{1}}{R_{2}} \stackrel{?}{=} \frac{P_{1}}{P_{2}}
$$

where $R_{1}$ is the number of intervals containing acoustic biomass, $R_{2}$ is the total number of intervals sampled, $P_{1}$ is the number of intervals containing birds that also contained acoustic biomass, and $P_{2}$ is the total number of intervals containing birds. If $P_{1} / P_{2}>R_{1} / R_{2}$, then birds co-occurred with acoustic biomass more often than expected by chance. If $P_{1} / P_{2}=R_{1} / R_{2}$, then marine bird distribution was simply proportional to the availability of acoustic biomass on those days. If $P_{1} / P_{2}<R_{1} / R_{2}$, then birds avoided intervals containing acoustic biomass. I used $2 \times 2$ contingency tables and Fisher's exact tests to evaluate the null hypothesis that $P_{1} / P_{2}=R_{1} / R_{2}$ on all sampling days, as well as on days when regional prey abundance was low and, separately, on days when regional prey abundance was high.

Numerical concordance: As the degree of spatial correlation between seabirds and prey can be highly dependent upon the spatial scale at which correlations are measured (Hunt \& Schneider 1987, Schneider 1994), numerical concordance between densities of acoustic biomass and marine birds in Monterey Bay was determined at 7 spatial scales: $0.2,0.4,0.8$, $1.6,3.2,5.6$, and $7.6 \mathrm{~km}$. At each scale, correlation strength was determined by calculating Pearson's correlation coefficients (r), coupled with Monte Carlo tests of significance. Heinemann et al. (1989) suggested that numerical concordance between predator and prey densities should only be assessed for intervals in which predators are observed rather than for all intervals along a transect. They argued that, if prey were more abundant than predators, low correlation coefficients could arise, not for meaningful biological reasons but because there are not enough predators to account for all of the prey. As this scenario is especially likely to exist in comparisons of correlation strength between days with relatively high versus relatively low prey abundance, correlation coefficients for marine birds and acoustic biomass in Monterey Bay were only calculated using intervals that contained birds. This step results in analyses that evaluate whether observed marine bird densities reflect the density of prey in the water column below them. Bird density was considered correlated with acoustic biomass density when the correlation coefficient for the observed association was greater than correlation coefficients for random associations in over $95 \%$ of 999 randomized trials (Chen \& Dunlap 1993).

I evaluated numerical concordance between marine birds and acoustic biomass by calculating $r$ for (1) all sampling days combined, (2) days when regional prey abundance was low and, separately, days when regional prey abundance was high; and (3) days on which regional prey abundance was very low, low, high, and very high. Small sample sizes at the larger spatial scales limited the latter analyses to spatial scales ranging from 0.2 to $3.2 \mathrm{~km}$. 


\section{RESULTS}

A total of 33 surveys (1998: $\mathrm{n}=9,1999: \mathrm{n}=9$, 1999/ 2000: $n=15$ ) were conducted during the winters of 1998 to 2000. Each survey sampled an average $( \pm$ SE) of $22.8( \pm 1.3) \mathrm{km}$. Rhinoceros auklets were the most abundant of the 4 marine bird species, followed in decreasing order by Pacific loons, common murres, and Brandt's cormorants (Table 1). These 4 species represented $43 \%$ of all birds (37 species total) observed during the study.

Regional densities of acoustic biomass were highly variable between consecutive sampling days (Table 1), indicating a relatively high degree of short-term (weekly) variation in potential prey availability to marine birds in nearshore Monterey Bay. Echograms revealed discrete patches of acoustic biomass distributed along transects, with most patches $\leq 0.2 \mathrm{~km}$ in diameter. Incidentally, significant interannual differences in the density of acoustic biomass sampled were not detected, even though part of the study was conducted during the 1998 El Nino event (ANOVA: $0.26<$ $F<1.15,0.329<\mathrm{p}<0.773$, depending on depth).

Days with high regional prey abundance $(\mathrm{n}=16)$ had, on average, 22 to 54 times more acoustic biomass present than did days with low regional prey abundance $(n=17)$ (Fig. 2a). Despite these differences, only densities of common murres were significantly higher on days with high prey abundance $\left(t^{2}{ }_{31}=2.04\right.$, $\mathrm{p}=0.025$ ) (Fig. 2b). Murre densities also tended to increase with prey abundance on days with very low $(\mathrm{n}=9)$, low $(\mathrm{n}=7)$, high $(\mathrm{n}=8)$, and very high $(\mathrm{n}=9)$ regional prey abundance $\left(\mathrm{n}=9 ; F_{3,32}=2.73, \mathrm{p}=0.062\right.$ ) (Fig. 2d). Densities of other birds showed no significant differences among these categories (Fig. 2d).

\section{Autocorrelation}

Acoustic biomass showed no evidence of spatial autocorrelation at any of the spatial scales examined when all sampling days were combined, regardless of the depth to which biomass was integrated $(-0.15<$ Moran's $I<0.07)$. The absence of spatial autocorrelation in the acoustic data indicates a lack of spatial structure that would have reduced the validity of crosscorrelation analyses. This result was not unexpected because the analysis only included measurement intervals that contained birds, which were often patchily distributed.

Marine birds showed some, but little, evidence of spatial autocorrelation. Pacific loons were negatively autocorrelated at the $3.2 \mathrm{~km}$ spatial scale (Moran's $I=-0.38, \mathrm{p}<0.001)$. When loon densities were regressed against acoustic biomass at this spatial scale, the residuals of the cross-correlation were also negatively autocorrelated (Moran's $I=-0.23$, p < 0.001), indicating spatial structure in the distribution of Pacific loons that was not attributable to acoustic biomass. This comparison was omitted from further analysis. On days
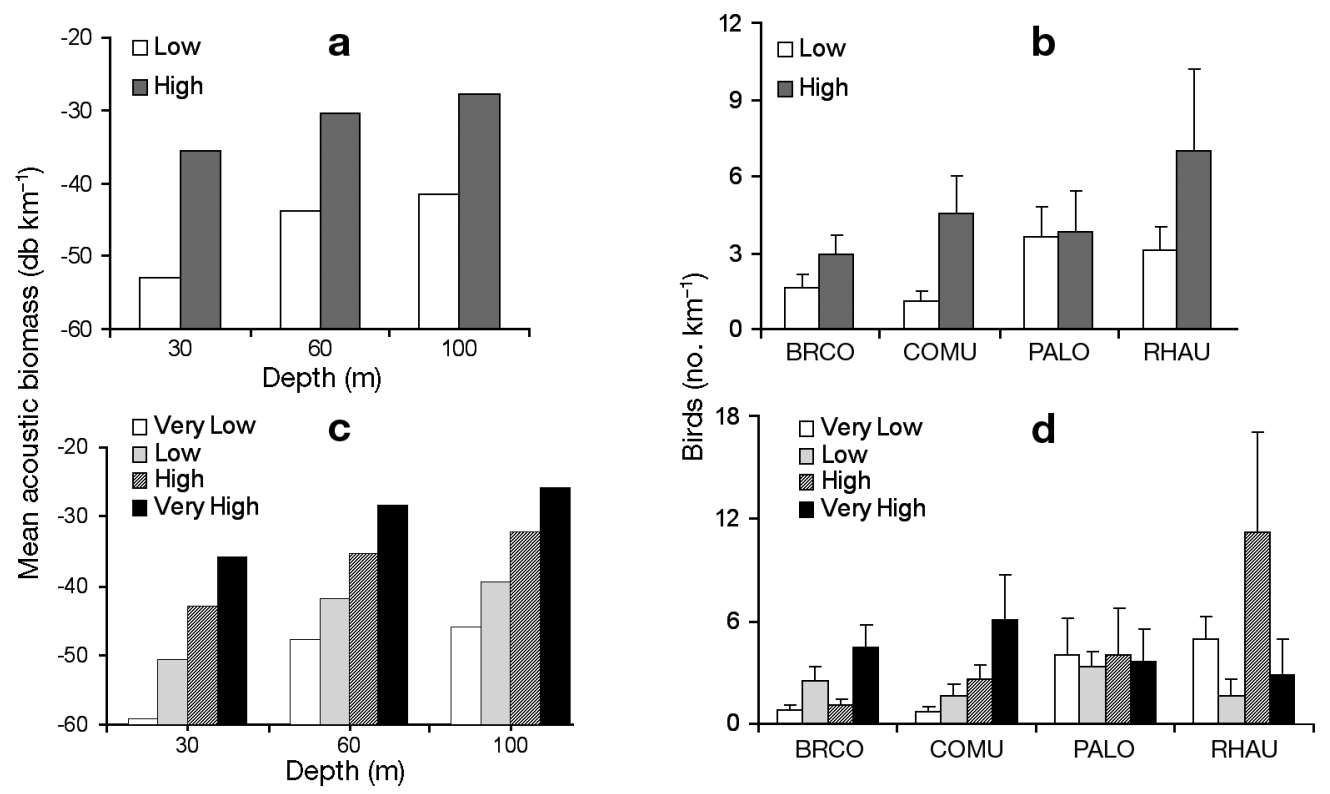

Fig. 2. Mean (+SE) density of (a) acoustic biomass $\left(\mathrm{dB} \mathrm{km}^{-1}\right)$ and (b) marine birds (birds km ${ }^{-1}$ ) on days when regional prey abundance was low and high. Mean density of (c) acoustic biomass $\left(\mathrm{dB} \mathrm{km}^{-1}\right)$ and (d) marine birds on days when regional prey abundance was very low, low, high, and very high. BRCO: Brandt's cormorant; COMU: common murre; PALO: Pacific loon; RHAU: rhinoceros auklet. Depth indicates the depth to which acoustic biomass was integrated (i.e. 4 to $30 \mathrm{~m}, 4$ to $60 \mathrm{~m}, 4$ to $100 \mathrm{~m}$ ) 
when regional prey abundance was low, common murres were negatively autocorrelated at the $5.6 \mathrm{~km}$ scale (Moran's $I=-1.2, \mathrm{p}=0.031$ ). When common murre densities were regressed against acoustic biomass at this spatial scale, the residuals were not autocorrelated (Moran's $I=-0.001, \mathrm{p}=0.415$ ); therefore, this comparison was retained in further analyses. On days with low prey densities, both Brandt's cormorants (Moran's $I=0.47, \mathrm{p}=0.032$ ) and acoustic biomass to $100 \mathrm{~m}$ depth (Moran's $I=0.69, \mathrm{p}=0.008$ ) were positively autocorrelated, but the residuals of the cross-correlation were not (Moran's $I=-0.004, \mathrm{p}=0.355$ ).

\section{Spatial concordance}

Spatial concordance between marine birds and acoustic biomass varied in strength among species. Brandt's cormorants were only associated with acoustic biomass when regional prey abundance was high (low: $p=0.087$, high: $p=0.003$ ) (Fig. 3b). Common
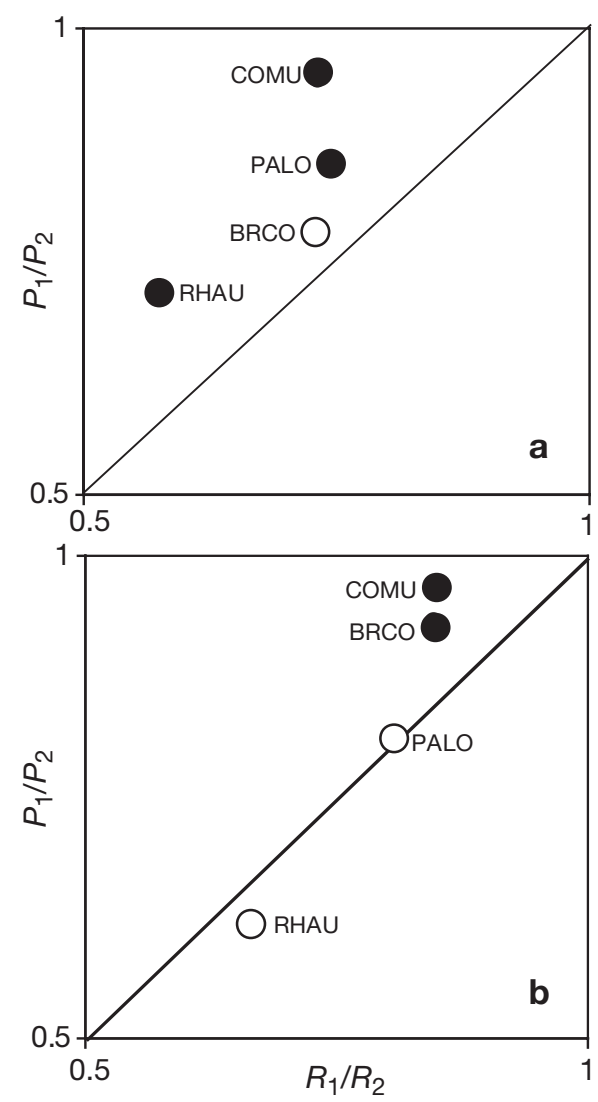

Fig. 3. Spatial concordance between acoustic biomass and marine birds on days when regional prey abundance was (a) low and (b) high. The solid line represents $R_{1} / R_{2}=P_{1} / P_{2}$, the null hypothesis. @: p < 0.05. BRCO: Brandt's cormorant; COMU: common murre; PALO: Pacific loon; RHAU: rhinoceros auklet murres were associated with acoustic biomass more often than expected by chance, regardless of regional prey abundance (low: p < 0.001, high: p < 0.001) (Fig. 3a,b). In contrast, Pacific loons (low: $p=0.002$, high: $p=0.517$ ) (Fig. 3a) and rhinoceros auklets (low: $\mathrm{p}<0.001$, high: $\mathrm{p}=0.126$ ) (Fig. 3a) were only significantly concordant with acoustic biomass when regional prey abundance was low.

\section{Numerical concordance}

No evidence was found for numerical concordance (i.e. cross-correlation) between acoustic biomass and marine birds when data from all sampling days were combined (Figs. 4a-7a). However, when data from days with low and high regional prey abundance were examined separately, there were marked differences in correlation strength between days. Densities of Brandt's cormorants $(0.28<\mathrm{r}<0.73,0.008<\mathrm{p}<$

\section{Brandt's cormorant}
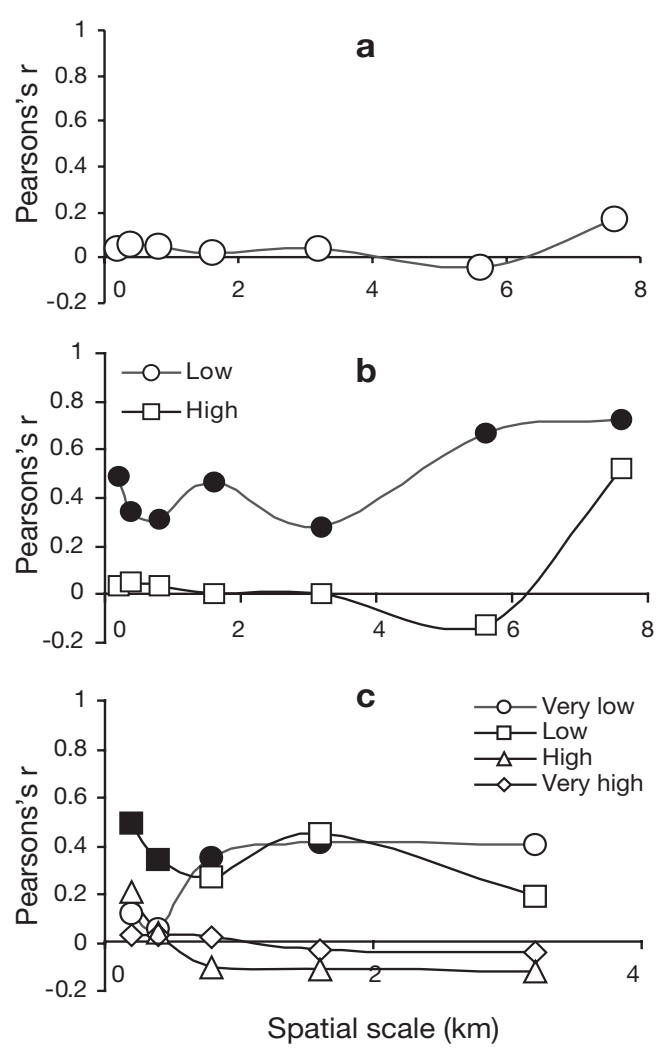

Fig. 4. Pearson's correlation coefficient (r) for the relationship between the densities of acoustic biomass and Brandt's cormorant in Monterey Bay (a) when all sampling days were combined, (b) on days when regional prey abundance was low and high, and (c) on days when regional prey abundance was very low, low, high, and very high. $\mathbf{0}$ : $\mathrm{p}<0.05$. Only measurement intervals containing cormorants were included 
Common murre
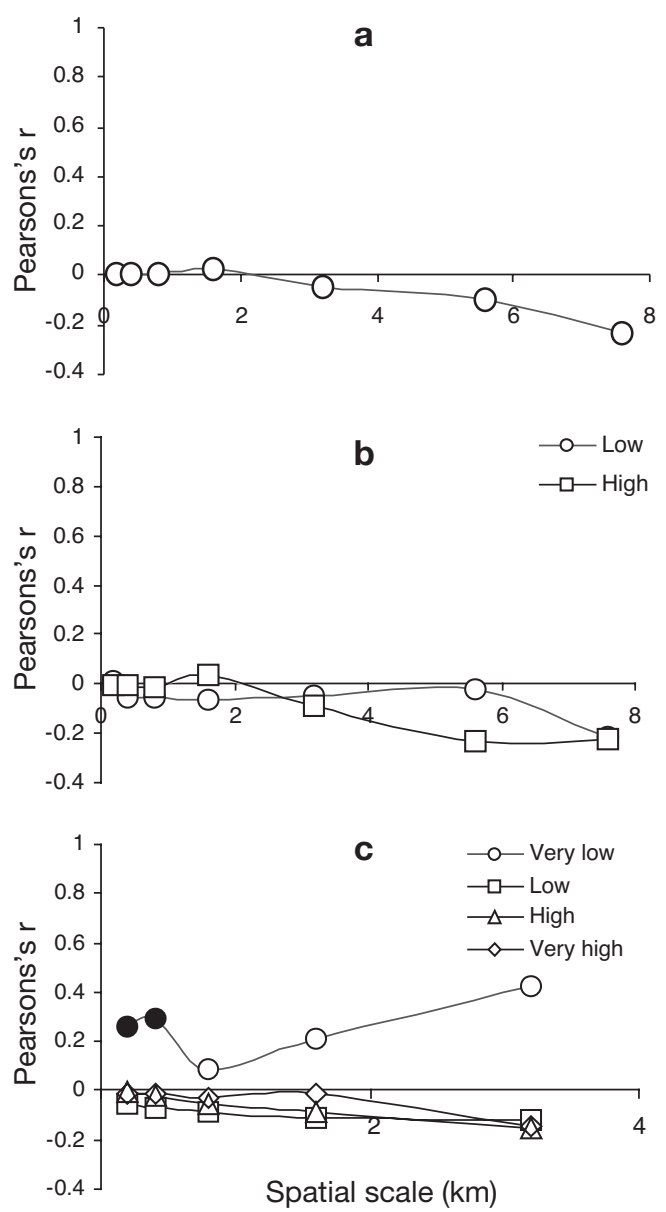

Fig. 5. Pearson's correlation coefficient (r) for the relationship between the densities of acoustic biomass and the common murre in Monterey Bay (a) when all sampling days were combined, (b) on days when regional prey abundance was low and high, and (c) on days when regional prey abundance was very low, low, high, and very high. $-\mathrm{p}$ : $<0.05$. Only measurement intervals containing murres were included

0.037, depending on spatial scale), Pacific loons $(0.32<$ $\mathrm{r}<0.045,0.003<\mathrm{p}<0.016)$, and rhinoceros auklets $(0.21<\mathrm{r}<0.28,0.028<\mathrm{p}<0.050)$ were only crosscorrelated with densities of acoustic biomass on days when regional prey abundance was low (Figs. 4b, 6b $\& 7 b)$. Brandt's cormorants were no longer correlated with acoustic biomass at the smallest spatial scales $(0.2$ to $0.4 \mathrm{~km})$, when regional prey abundance was very low $(0.06>\mathrm{r}>0.12)$ (Fig. $4 \mathrm{c}$ ). In contrast, common murres were significantly correlated with acoustic biomass only on days when regional prey abundance was very low $(\mathrm{r}=0.26, \mathrm{p}=0.019)$ (Fig. 5c). Significant correlations between densities of acoustic biomass and densities of Pacific loons ( $\mathrm{r}=$ 0.27, $\mathrm{p}=0.006$ ) (Fig. 6c) and rhinoceros auklets ( $\mathrm{r}=$ $0.27, p=0.004$ ) (Fig. $7 \mathrm{c}$ ) at the smallest spatial scale
Pacific loon
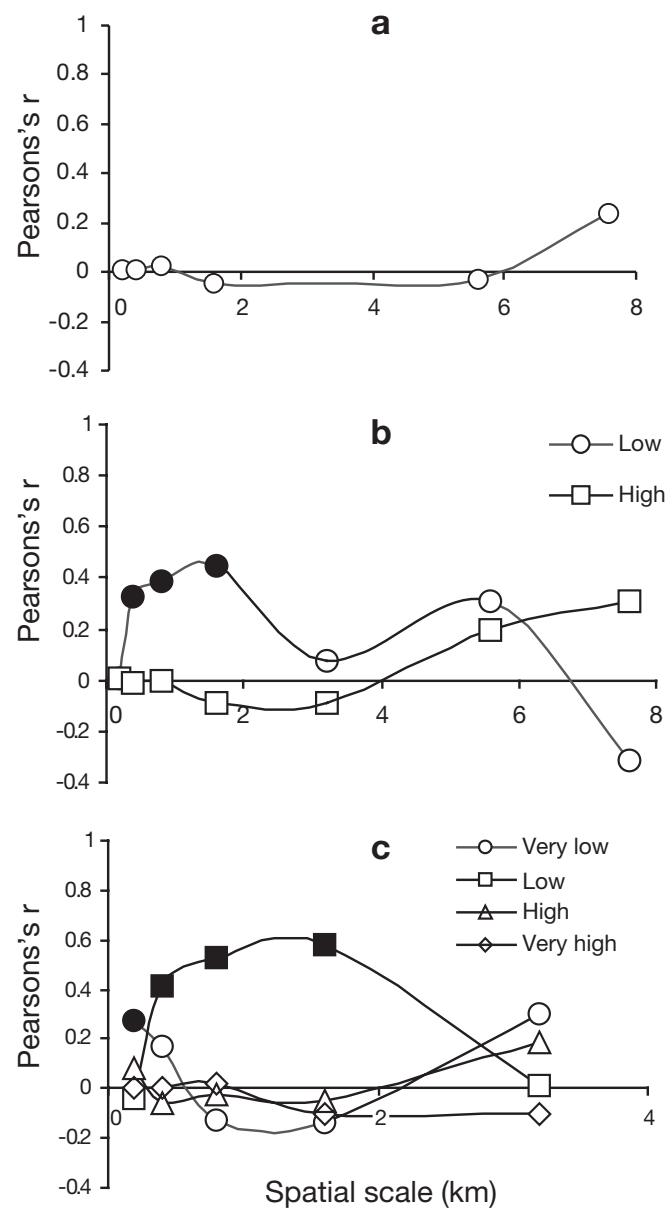

Fig. 6. Pearson's correlation coefficient (r) for the relationship between the densities of acoustic biomass and the Pacific loon in Monterey Bay (a) when all sampling days were combined, (b) on days when regional prey abundance was low and high, and (c) on days when regional prey abundance was very low, low, high, and very high. $\mathbf{0}: \mathrm{p}<0.05$. Only measurement intervals containing loons were included

(0.2 km), only occured when regional prey abundance was very low.

\section{DISCUSSION}

The results of this study support the hypothesis that the extent to which marine bird densities reflect prey densities over small spatial scales is, at least partially, dependent upon prey availability at larger spatial scales. Pacific loons and rhinoceros auklets were only spatially concordant with acoustic biomass when regional prey abundance was relatively low, and all 4 marine bird species were only numerically concordant with acoustic biomass when regional prey abundance was relatively low. As the composition of acoustic bio- 

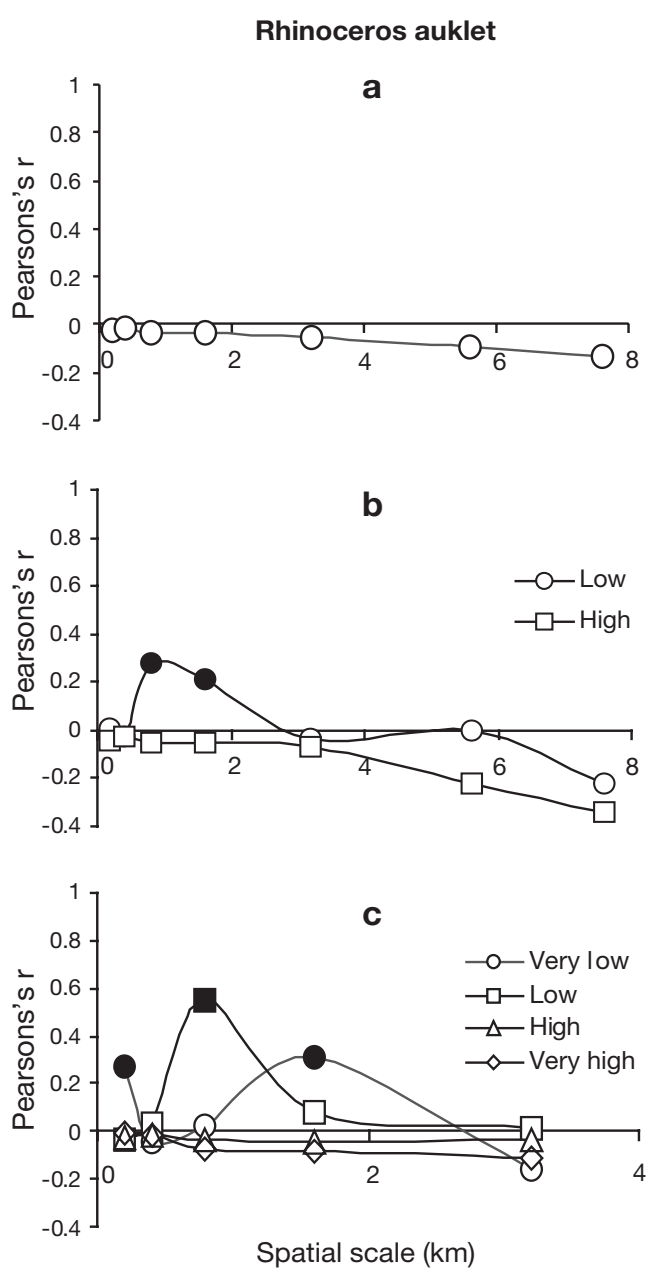

Fig. 7. Pearson's correlation coefficient (r) for the relationship between the densities of acoustic biomass and the rhinoceros auklet in Monterey Bay (a) when all sampling days were combined, (b) on days when regional prey abundance was low and high, and (c) on days when regional prey abundance was very low, low, high, and very high. $\bullet$ : $\mathrm{p}<0.05$. Only measurement intervals containing auklets were included

mass was not determined, I cannot rule out the possibility that biomass on days with high regional prey abundance represented biomass that was not prey for marine birds; however, the observation that densities of all 4 marine bird species, each of which possesses a relatively broad piscivorous diet, failed to correlate with acoustic biomass on those days, suggests that the pattern was not driven by a lack of interest in particular food items.

Unlike other authors (Heinemann et al. 1989, Erikstad et al. 1990, Piatt 1990, Hunt et al. 1992, Logerwell \& Hargreaves 1996), I did not find correlation strength to increase with measurement scale. This may be related to the fact that the largest spatial scale at which correlations were examined $(7.6 \mathrm{~km})$ was not much smaller than the regional spatial scale $(20 \mathrm{~km})$, and the sample size was relatively small at the largest measurement scale. For this and other reasons (see 'Materials and methods'), the results of this study are interpreted in terms of differences in correlation strength between days with contrasting regional prey abundance rather than in terms of the spatial scales at which correlations were observed.

In addition to Monterey Bay, short-term fluctuations in correlation strength have been observed in communities off the coasts of Newfoundland (Schneider \& Piatt 1986) and British Columbia (Burger et al. 2004). In both cases, variation occurred among sampling days. In other studies conducted off the coasts of Scotland (Wright \& Begg 1997) and British Columbia (Davoren et al. 2002), authors observed correlation strength to vary seasonally, and, in a different study conducted off the coast of Scotland, correlation strength varied annually (Wright \& Bailey 1993). Temporal variation in correlation strength is not limited to associations measured over small spatial scales. Off the coast of Norway, daily variation existed in the strength of spatial associations between murres and prey measured over a $200 \mathrm{~km}$ spatial scale (Fauchald \& Erikstad 2002).

Behavioral mechanisms responsible for causing the strength of small-scale spatial associations between marine birds and prey to fluctuate over time likely involve factors that affect the need or ability of birds to track prey. For example, when prey is superabundant, marine birds may not track prey because doing so would be energetically inefficient (Woodby 1984), especially when prey is highly mobile and prey-tracking requires great energy expenditure (Huey \& Pianka 1981, Hunt et al. 1990). When they compared the energetic needs of Atlantic cod Gadus morhua off Newfoundland to regional prey (capelin) abundance, Horne \& Schneider (1994) found evidence for the benefit of predators not tracking prey when prey abundance was high. Given the relatively large amount of capelin (energy) available to cod, cod could forage more efficiently as sit-and-wait predators than they could by pursuing individual fish. Like cod, marine birds in Monterey Bay feed on highly mobile prey. Feeding on nearby prey instead of traveling to areas of maximum prey abundance when prey was highly abundant may have been a more efficient foraging mode for birds in Monterey Bay than was pursuing individual fish schools. Woodby (1984) also suggested that, at his study site in the Bering Sea, thick-billed murres did not track prey over small $(<6 \mathrm{~km})$ spatial scales because prey was sufficiently abundant for birds to ambush prey than to track prey over large distances.

When regional prey abundance declines from superabundant to intermediate levels, difficulties may begin to arise in the ability of marine birds to locate and fol- 
low profitable prey patches. Birds may, therefore, adjust their foraging behavior to minimize costs related to searching for prey. They could accomplish this by spending more time in the vicinity of known prey patches or to acquire information on prey location by watching the foraging activity of conspecifics (Davoren et al. 2003). They could also spend more time in areas with temporally predictable food supplies, such as those containing hydrographic fronts or upwelling (Schneider 1989, 1990, Hunt et al. 1990, 1999, Decker \& Hunt 1996, Parrish et al. 1998, Skov et al. 2000, Vlietstra et al. in press). In addition, theory predicts that when food is in relatively high demand, foragers can minimize within-patch competition by distributing themselves in proportion to the profitability of prey patches (Fretwell \& Lucas 1970). This pattern is called the Ideal Free Distribution (IFD), and foragers are expected to resemble the IFD more closely when food availability is low than when food is superabundant. Marine birds in Monterey Bay more closely resembled the IFD when regional prey abundance was relatively low. A similar pattern was observed among common murres off the coast of Scotland, where murres were significantly associated with their sandeel prey during a year of low sandeel abundance, but not during subsequent years when sandeels were relatively abundant (Wright \& Bailey 1993). The distribution of common murres off Newfoundland also more closely approximated the IFD in a region where capelin were ephemeral than in a region where capelin were persistently abundant (Davoren et al. 2003).

When regional prey abundance declines from intermediate to very low levels, constraints may begin to prevent predators from tracking prey (see Balance et al. 2001). There may be morphological constraints, such as a bird's flight efficiency or ability to locate or follow prey (Balance et al. 1997, Davoren et al. 2002), or they can be perceptual, such as a predator's ability to design effective foraging strategies when prey-encounter rates are too low (Abrahams 1986, Gray \& Kennedy 1994, Tyler \& Clapp 1995, Fauchald 1999). An individual's ability to track prey may also be limited by social constraints, such as the exclusion of foragers by competitors in otherwise profitable patches (Fretwell \& Lucas 1970, Fretwell 1972). For example, Piatt (1987) observed common murres excluding the Atlantic puffin Fratercula arctica from certain feeding areas in waters off Newfoundland. In Monterey Bay, only densities of Brandt's cormorants failed to correlate with densities of acoustic biomass at the smallest spatial scales $(0.2$ to $0.4 \mathrm{~km})$ when regional prey abundance was very low. It is unclear what constraints, if any, may have been involved in this case.

Causes of variation among studies in the degree to which seabirds track prey over small spatial scales have so far been difficult to resolve, not only because correlation strength is scale-dependent and temporally variable, but also because studies report major differences in the direction of seabird responses to prey declines; that is, reduced prey availability appears to elicit stronger spatial associations in some cases (Wright \& Bailey 1993, this study) but weaker associations in others (Mehlum et al. 1999, Fauchald \& Erikstad 2002). The present study was not designed to test hypotheses about variation among studies in the direction of seabird responses to regional prey declines, but behavioral mechanisms already discussed may help to explain some of the conflicting results. For example, studies reporting stronger correlations between marine birds and prey when prey availability declined (Wright \& Bailey 1993, this study) may have characterized seabird responses to high and intermediate levels of absolute prey abundance. If so, prey-tracking could have shifted from being an energetically inefficient foraging strategy to being profitable when absolute prey abundance shifted from a high to an intermediate level. In contrast, studies reporting weaker correlations between marine birds and prey when prey availability declined, may have characterized responses to intermediate and low levels of absolute prey abundance. In this case, birds may have tracked prey until constraints prevented them from doing so when absolute prey abundance was low. Differences among studies in the direction of seabird responses to regional prey fluctuations may also arise for other important reasons, such as seasonal changes in the foraging needs and constraints of seabirds (Davoren et al. 2002). These ideas do, however, highlight the importance of authors reporting not only relative prey abundance but also absolute prey abundance at their study sites. Ideally, regional prey abundance would be reported in $\mathrm{g} \mathrm{m}^{-3}$, but logistical problems with obtaining necessary conversion data may preclude such detail. In that case, prey densities in terms of $\mathrm{dB} \mathrm{m}^{-3}$ for a given acoustic frequency may allow for preliminary, yet informative, comparisons.

In conclusion, spatial and numerical concordance between marine birds and acoustically-determined prey biomass in Monterey Bay were, at least partially, dependent upon regional prey abundance. I propose that fluctuations in regional prey availability account for some of the variation previously observed in the strength of small-scale spatial associations between marine birds and their prey. This idea is relevant to marine conservation, especially with regard to recently proposed offshore marine reserves. By protecting critical feeding sites in the open ocean, these reserves are intended, in part, to protect top marine predators and the assemblages upon which they feed (Mills \& Carleton 1998, Hooker et al. 1999, Hyrenbach et al. 2000, Pelagic Working Group 2002 unpubl. workgroup pro- 
ceedings). If regional prey abundance influences the extent to which marine birds track prey over small spatial scales, reserves may be most effective in preserving trophic linkages during times of year when prey outside the reserve occurs in intermediate abundance relative to a predator's foraging needs.

Acknowledgements. I gratefully acknowledge funding from the National Geographic Society, the North American Loon Fund, and the Dr. William F. Holcomb Scholarship in Marine Science from the University of California, Irvine. I would also like to thank Moss Landing Marine Laboratories, Oikos Research Foundation, and the San Francisco Bay Bird Observatory for providing logistical support for the study. I thank G. Hunt and J. McIntyre for discussing with me ideas reflected in the manuscript. The study was made possible, in part, by field assistance provided by L. Bradford, T. Thomas, T. Ryan, J. Ryan, J. Faust, and R. Goodman. I am equally grateful for the constructive comments made on the original manuscript by G. Hunt, M. Patrick, L. Ballance, W. Sydeman, A. Burger, and 2 anonymous referees.

\section{LITERATURE CITED}

Abrahams MV (1986) Patch choice under perceptual constraints: a cause for departures from an ideal free distribution. Behav Ecol Sociobiol 19:409-415

Ainley DG (1990) Farallon seabirds: patterns at the community level. In: Ainley, DG, Boekelheide RJ (eds) Seabirds of the Farallon Islands. Stanford University Press, Stanford, CA, p 349-380

Ainley DG, Sanger GA (1979) Trophic relationships of seabirds in the northeastern Pacific Ocean and Bering Sea. In: Bartonek JC, Nettleship DN (eds) Conservation of marine birds of North America. Stanford University Press, Stanford, CA, p 95-122

Ainley DG, Anderson DW, Kelly PR (1981) Feeding ecology of marine cormorants in southwestern North America. Condor 83:120-131

Ainley DG, Spear LB, Allen SG, Ribic CA (1996) Temporal and spatial patterns in the diet of the common murre in California waters. Condor 98:691-705

Ainley DG, Nettleship DN, Carter HR, Storey AE (2002) Common murre Uria aalge. No. 666. In: Poole A, Gill F (eds) Birds of North America. The Academy of Natural Sciences, Philadelphia and The American Ornithologists' Union, Washington, DC, p 1-39

Ballance LT, Pitman RL, Reilly SB (1997) Seabird community structure along a productivity gradient: importance of competition and energetic constraint. Ecology 78: 1502-1518

Ballance LT, Ainley DG, Hunt GL Jr (2001) Seabird foraging ecology. In: Steele JH, Thorpe SA, Turekian KK (eds) Encyclopedia of ocean sciences Vol 5. Academic Press, London, p 2636-2644

Baltz DM, Morejohn GV (1977) Food habits and niche overlap of sea birds wintering on Monterey Bay, California. Auk 94:526-543

Barange M, Hampton I, Soule M (1996) Empirical determination of in situ target strengths of three loosely aggregated pelagic fish species. ICES J Mar Sci 53:225-232

BioSonics (1998) Visual Analyzer 4.0.2. BioSonics, Seattle, WA
Breaker LC, Broenkow WM (1994) The circulation of Monterey Bay and related processes. Ocean Mar Biol Annu Rev 32:1-64

Brierley AS, Ward P, Watkins JL, Goss C (1998) Acoustic discrimination of Southern Ocean zooplankton. Deep-Sea Res II 45:1155-1173

Burger AE, Wilson RP, Garnier D, Wilson MPT (1993) Diving depths, diet, and underwater foraging of rhinoceros auklets in British Columbia. Can J Zool 71:2528-2540

Burger AE, Hitchcock CL, Davoren GK (2004) Spatial aggregations of seabirds and their prey on the continental shelf off SW Vancouver Island. Mar Ecol Prog Ser 283:279-292

Cailliet GM, Karpov KA, Ambrose DA (1979) Pelagic assemblages as determined from purse seine and large midwater trawl catches in Monterey Bay and their affinities with the market squid, Loligo opalescens. CalCOFI Rep 20: 21-30

Chen RS, Dunlap WP (1993) SAS procedures for approximate randomization tests. Behav Res Meth Inst Comp 25: 406-409

Clay CI (1911) Some diving notes on cormorants. Condor 13: 138

Croll DA (1989) Determinants of the diet and distribution of the common murre (Uria aalge) in Monterey Bay, California. MSc thesis, California State University, Fresno, CA

Coyle KO, Pinchuk AI (2002) The abundance and distribution of euphausiids and zero-age Pollock on the inner shelf of the southeast Bering Sea near the Inner Front in 1997-1999. Deep-Sea Res II 49:6009-6030

Davoren GK, Montevecchi WA, Anderson JT (2002) Scaledependent associations of predators and prey: constraints imposed by flightlessness of common murres. Mar Ecol Prog Ser 245:259-272

Davoren, GK, Montevecchi WA, Anderson JT (2003) Distributional patterns of a marine bird and its prey: habitat selection based on prey and conspecific behavior. Mar Ecol Prog Ser 256:229-242

Decker MB, Hunt GL Jr (1996) Foraging by murres (Uria spp.) at tidal fronts surrounding the Pribilof Islands, Alaska, USA. Mar Ecol Prog Ser 139:1-10

Diniz-Filho JAF, Bini LM, Hawkins BA (2003) Spatial autocorrelation and red herrings in geographical ecology. Global Ecol Biogeogr 12:53-64

Erikstad KE, Moum T, Vader W (1990) Correlations between pelagic distribution of the common and Brunnich's guillemots and their prey in the Barents Sea. Polar Res 8:77-87

Fagen R (1987) A generalized habitat matching rule. Evol Ecol 1:5-10

Fauchald P (1999) Foraging within a hierarchical patch system. Am Nat 153:603-613

Fauchald P, Erikstad KE (2002) Scale-dependent predatorprey interactions: the aggregative response of seabirds to prey under variable prey abundance and patchiness. Mar Ecol Prog Ser 231:279-291

Fauchald P, Erikstad KE, Skarsfjord H (2000) Scale-dependent predator-prey interactions: the hierarchical spatial distribution of seabirds and prey. Ecology 81:773-783

Fretwell SD (1972) Populations in a seasonal environment. Princeton University Press, Princeton, NJ

Fretwell SD, Lucas HL Jr (1970) On territorial behavior and other factors influencing habitat distribution in birds. Acta Biotheoretica 19:16-36

Garrison DL (1979) Monterey Bay phytoplankton I. Seasonal cycles of phytoplankton assemblages. J Plankton Res 1: 241-265

Gaston AJ, Dechesne SBC (1996) Rhinoceros auklet Cerorhinca monocerata. No. 212. In: Poole A, Gill F (eds) Birds 
of North America. The Academy of Natural Sciences, Philadelphia and The American Ornithologists' Union, Washington, DC, p 1-19

Gray RD, Kennedy M (1994) Perceptual constraints on optimal foraging: a reason for departures from the ideal free distribution? Anim Behav 47:469-471

Gutiérrez M, MacLennan DN (1998) Resultados preliminarios de las mediciones de fuerza de blanco in situ de las principales especies pelagicas. Crucero BIC Humboldt 9803-05 de Tumbes a Tacna. Inf Inst Mar Peru 135:16-19 (in Spanish with English abstract)

Heinemann D, Hunt GL Jr, Everson I (1989) Relationships between the distributions of marine avian predators and their prey, Euphausia superba, in Bransfield Strait and southern Drake Passage, Antarctica. Mar Ecol Prog Ser 58:3-16

Hooker SK, Whitehead H, Gowans S (1999) Marine protected area design and the spatial and temporal distribution of cetaceans in a submarine canyon. Conserv Biol 13:592-602

Horne J, Clay CS (1998) Sonar systems and aquatic organisms: matching equipment and model parameters. Can J Fish Aquat Sci 55:1296-1306

Horne J, Schneider DC (1994) Lack of spatial coherence of predators with prey: a bioenergetic explanation for Atlantic cod feeding on capelin. J Fish Biol 45:191-207

Huey RB, Pianka ER (1981) Ecological consequences of foraging mode. Ecology 62:991-999

Hunt GL Jr, Schneider DC (1987) Scale-dependent processes in the physical and biological environment of marine birds. In: Croxall JP (ed) Seabirds: feeding biology and role in ecosystems. Cambridge University Press, Cambridge, p 7-41

Hunt GL Jr, Harrison NM, Cooney T (1990) The influence of hydrographic structure and prey abundance on foraging of least auklets. Stud Avian Biol 14:7-22

Hunt GL Jr, Heinemann D, Everson I (1992) Distributions and predator-prey interactions of macaroni penguins, Antarctic fur seal, and Antarctic krill near Bird Island, South Georgia. Mar Ecol Prog Ser 86:15-30

Hunt GL Jr, Mehlum F, Russell RW, Irons D, Decker MB, Becker PH (1999) Physical processes, prey abundance, and the foraging ecology of seabirds. In: Adams N, Slotow $\mathrm{R}$ (eds) Proceedings of the 22nd International Ornithological Congress. University of Natal, Durban. Birdliife South Africa, Johannesburg, p 2040-2056

Hyrenbach, KD, Forney KA, Dayton PK (2000) Marine protected areas and ocean basin management. Aquat Conserv Mar Freshw Ecosyst 10:437-458

Kawabata A (1999) Measurement of the target strength of Japanese flying squid, Todarodes pacificus Steenstrup. Bull Tohoku Nat Fish Res Inst 61:29-40

Kudela RK, Dugdale RC (1996) Estimation of new production from remotely-sensed data in a coastal upwelling regime. Adv Space Res 18:91-97

Kuroki M, Kato A, Watanuki Y, Niizuma Y, Takahashi A, Naito Y (2003) Diving behavior of an epipelagically feeding alcid, the Rhinoceros Auklet (Cerorhinca monocerata). Can J Zool 81:1249-1256

Legendre P (1993) Spatial autocorrelation: trouble or a new paradigm? Ecology 74:1659-1673

Legendre P, Dale MRT, Fortin MJ, Gurevitch J, Hohn M, Myers D (2002) The consequences of spatial structure for the design and analysis of ecological field surveys. Ecography 25:601-615

Lima S (1983) Downy woodpecker foraging behavior: foraging by expectation and energy intake rate. Oecologia 58: 232-237

Logerwell EA, Hargreaves NB (1996) The distribution of sea birds relative to their fish prey off Vancouver Island: opposing results at large and small spatial scales. Fish Oceanogr 5:163-175

MacArthur RH, Pianka ER (1966) On optimal use of a patchy environment. Am Nat 100:603-609

Mason JW (1997) Distribution and abundance of seabirds in Monterey Bay, California. MSc thesis. California State University, Fresno, CA

McGegee DE, O'Driscoll RL, Traykovski LV (1998) Effects of orientation on acoustic scattering from Antarctic krill at 120 kHz. Deep-Sea Res II 45:1273-1294

Mehlum F, Hunt GL Jr, Klusek Z, Decker MB (1999) Scaledependent correlations between the abundance of Brünnich's guillemots and their prey. J Anim Ecol 68:60-72

Messier F, Virgil JA, Marinelli L (1990) Density-dependent habitat selection in muskrats: a test of the ideal free distribution model. Oecologia 84:380-385

Mills CE, Carlton JT (1998) Rationale for a system of international reserves for the open ocean. Conserv Biol 12:244-247

Misund OA, Beltestad AK (1996) Target-strength estimates of schooling herring and mackerel using the comparison methods. ICES J Mar Sci 53:281-284

Morejohn GV, Harvey JT, Kransnow LT (1978) The importance of Loligo opalescens in the food web of marine vertebrates in Monterey Bay, California. In: Recksiek CW, Frey HW (eds) Biological, oceanographic, and acoustic aspects of the market squid, Loligo opalescens Berry. Calif Dep Fish Game Game Bull 169:67-185

Obst BS (1985) Densities of Antarctic seabirds at sea and the presence of the krill Euphausia superba. Auk 102:540-549

Parrish JK, Lemberg N, South-Oryshchyn L (1998) Effects of colony location and nekton abundance on the at-sea distribution of four seabird species. Fish Oceanogr 7:126-135

Pianka ER (1986) Ecology and natural history of desert lizards. Analyses of the ecological niche and community structure. Princeton University Press, Princeton, NJ

Piatt JF (1987) Behavioural ecology of common murre Uria aalge attendance patterns at Cape St. Mary's, Newfoundland. Can J Zool 65:1530-1534

Piatt JF (1990) The aggregative response of common murres and Atlantic puffins to schools of capelin. Stud Avian Biol 14:36-51

Piatt JF, Nettleship DN (1985) Diving depths of four alcids. Auk 102:293-97

Pieper RE (1979) Euphausiid distribution and biomass determined acoustically at $102 \mathrm{kHz}$. Deep-Sea Res 26:687-702

Roberts TS (1932) The birds of Minnesota: Vol 1. University of Minnesota Press, Minneapolis, MN

Safina C, Burger J (1985) Common tern foraging: seasonal trends in prey fish densities and competition with bluefish. Ecology 66:1457-1463

Schneider DC (1989) Identifying the spatial scale of densitydependent interaction of predators with schooling fish in the southern Labrador Current. J Fish Biol 35(SA): 109-115

Schneider DC (1990) Seabirds and fronts: a brief overview. Polar Res 8:17-21

Schneider DC (1994) Scale-dependent patterns and species interactions in marine nekton. In: Giller PS, Hildrew AG, Raffaelli DG (eds) Aquatic ecology: scale, pattern and process. Blackwell Scientific Publications, Oxford, p 441-467

Schneider DC, Piatt JF (1986) Scale-dependent correlation of seabirds with schooling fish in a coastal ecosystem. Mar Ecol Prog Ser 32:237-246

Schoener TW (1971) Theory of feeding strategies. Annu Rev Ecol Syst 2:369-404

Skov H, Durinck J, Andell P (2000) Associations between win- 
tering avian predators and schooling fish in SkagerrakKattegat suggest reliance on predictable aggregations of herring Clupea harengus. J Avian Biol 31:135-143

Spencer HG, Kennedy M, Gray RD (1996) Perceptual constraints on optimal foraging: the effects of variation among foragers. Evol Ecol 10:331-339

Stephens DW, Krebs JR (1987) Foraging theory. Princeton University Press, Princeton, NJ

Tyler JA, Clapp DP (1995) Perceptual constraints on stream fish habitat selection: effects of food availability and water velocity. Ecol Fresh Fish 4:9-16

Vaughan DL, Recksiek CW (1979) Detection of market squid, Loligo opalescens, with echo sounders. CalCOFI Rep 20: 40-50

Vlietstra LS, Coyle KO, Kachel NB, Hunt GL Jr (in press) Tidal

Editorial responsibility: Michael Landry (Contributing Editor), La Jolla, California, USA front affects the size of prey used by a top marine predator. Fish Oceanogr

Watkins JL, Brierley AS (1996) A post-processing technique to remove background noise from echo integration data. ICES J Mar Sci 53:339-344

Woodby DA (1984) The April distribution of murres and prey patches in the southeastern Bering Sea. Limnol Oceanogr 29:181-188

Wright PJ, Bailey MC (1993) Biology of sandeels in the vicinity of seabird colonies at Shetland. Fisheries report 15/93, Scottish Office Agriculture and Fisheries Department, Marine Laboratory, Aberdeen

Wright PJ, Begg GS (1997) A spatial comparison of common guillemots and sandeels in Scottish waters. ICES J Mar Sci 54:578-592

Submitted: December 30, 2003; Accepted: November 1, 2004 Proofs received from author(s): April 7, 2005 